issn: $1808-799 X$

ano 6 - número 7 - 2008

\title{
CONSIDERAÇÕES SOBRE A ORGANIZAÇÃO DAS IES PRIVADAS BRASILEIRAS: UMA ANÁLISE DAS PROPOSTAS DA ABMES - UMA ENTIDADE REPRESENTATIVA DO SETOR PRIVATISTA PARA O QUADRIÊNIO 2007-2011
}

\author{
Andréa Araujo do Vale - andreaavale@ig.com.br
}

\section{Introdução}

Este trabalho visa articular os elementos constituintes das condições objetivas em que se desenvolvem hoje as Instituições de Ensino Superiorii (IES) privadas. Utilizando uma metáfora talvez um pouco tosca, trata-se de compreender a montagem do "cenário" em que se

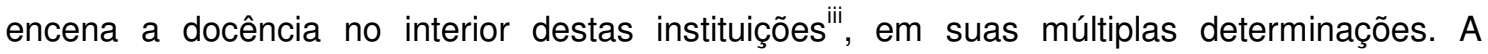
compreensão do estatuto do trabalho docente no ensino superior privado no Brasil só pode ser buscada no conjunto de mediações ${ }^{\text {iv }}$ que as conectam às transformações por que passam as sociedades capitalistas na contemporaneidade. Partir-se-á da atual configuração do regime de acumulação capitalista na tentativa de reconstituir os caminhos pelos quais se desenrola a contra-reforma da educação superior no Brasil. Essa reforma revela-se como projeto de empresariamento da educação superior (Neves, 2002), conduzido a partir das políticas dos organismos internacionais, como o Banco Mundial (BM), o Fundo Monetário Internacional (FMI) e a Organização Mundial do Comércio (OMC), configurando-se como parte da tentativa do capital de conter sua crise estrutural, aparente como crise do modelo fordista-keynesiano, que emergiu nos anos 1970.

Não se quer com isso dizer que estes órgãos sejam os únicos sujeitos artífices deste processo. O Estado brasileiro é o implementador do projeto econômico e político-social das burguesias locais - em especial, a nova burguesia de serviços ${ }^{v}$ - que, mais uma vez, optam por uma inserção subordinada ao capital internacional como chave de sua dominação interna. $\mathrm{Na}$ reforma da educação superior, empreendida sob égide neoliberal, a nova burguesia de serviços educacionais cria suas representações coletivas, capazes de defender e realizar pressões no sentido de criar as condições políticas e econômicas objetivas para a realização de seus interesses. É o caso da Associação Brasileira de Mantenedoras do Ensino Superior (ABMES), uma entidade representativa das mantenedoras das instituições privadas de ensino superior. Fundada em 1982 como conseqüência direta da expansão do setor privado laico nos 
issn: $1808-799 X$

ano 6 - número 7 - 2008

anos 1970, atua para assegurar os interesses dos empresários do ensino, como veremos mais adiante $^{\text {vi }}$. É no contexto da reforma neoliberal do Estado que crescem exponencialmente as IES privadas no país, chegando a ser, em 2005, responsáveis por $80,25 \%$ do número de alunos ingressantes neste nível de ensino vii. De maneira resumida, a hipótese aqui trabalhada é que tal crescimento é viabilizado, em boa parte, por dois vetores, dentre outros: o estímulo do Estado à iniciativa privada, não apenas sob a forma de privatizações que marcam, aliás, a política neoliberal em vigor, mas também através de formas variadas de financiamento público, e a organização do trabalho - especialmente dos docentes - no interior destas instituições.

Para consubstanciar este artigo, far-se-á aqui a análise do documento "Políticas Públicas para a Educação Superior. Propostas do Setor Privado", elaborado pela Associação Brasileira das Mantenedoras do Ensino Superior (ABMES), elaborado em 2006, com vistas ao quadriênio 2007-2010, em que apresenta ao governo os interesses e pensamentos do setor privado (ABMES, 2006, p.7) para a educação superior no Brasil, permitindo localizar no presente as linhas de força a conduzir as reivindicações/demandas do setor privado a marcar os próximos anos.

\section{As reformas da educação superior brasileira no contexto do regime de acumulação flexível-neoliberal}

Basta uma análise um pouco mais atenta das Sinopses Estatísticas da Educação Superior divulgadas pelo INEP para termos uma idéia da expansão da iniciativa privada neste setor da educação. Segundo a sinopse de 2006, das 2.270 IES no país, apenas 248 são públicas $^{\text {viii }}$ (federal, estadual e municipal) ${ }^{\text {ix }}$, ou seja, apenas aproximadamente $10,92 \%$. As privadas somam mais de $89 \%$. As públicas respondem por um total de 335.767 alunos ingressantes, oferecendo 6.549 cursos de graduação presenciais, enquanto que as privadas respondem por 1.417.301 ingressos ${ }^{x}$, ofertando 15.552 cursos presenciais. Se checarmos 0 número total de alunos, as diferenças ficam ainda mais gritantes: as IES públicas somam $\mathrm{m}$ total de 1.209.304 matrículas em cursos de graduação presenciais, enquanto as IES privadas reúnem 3.467.342 matrículas em cursos presenciais. O setor privado emprega 209.883 docentes $^{\mathrm{xi}}$, sendo que apenas 33.754 possuem regime de tempo integral de trabalho ${ }^{\mathrm{xii}}$, podendo implicar que um mesmo docente atenda um número grande de turmas, com uma ou 
issn: $1808-799 \mathrm{X}$

ano 6 - número 7 - 2008

mais disciplinas, em uma mesma ou em várias IES, ou mesmo que assuma outras funções em geral, administrativas - em alguma instituição.

De acordo com Neves e Fernandes (2002a), para que se possa compreender, em sua concretude, as mudanças recentes na educação no Brasil, na direção de seu crescente empresariamento, é preciso buscar suas várias determinações, dentro de um quadro geral das transformações socioeconômicas do capitalismo tardio (Rodrigues, 2007). Além da reestruturação produtiva que assinala o último quarto do século XX e início do século XXI,

Essas determinações devem ser buscadas, também: a) no papel que vem desempenhando o Brasil no capitalismo internacional nos tempos de mundialização do capital (Chesnais, 1996); b) no padrão neoliberal de desenvolvimento, em especial nas novas funções econômicas e de mediação política assumidas pelo Estado; c) na correlação de forças sociais, particularmente no que se refere às reivindicações educacionais dos vários sujeitos políticos coletivos, estrutural ou conjunturalmente agrupados em torno dos interesses da burguesia e do proletariado" (Neves e Fernandes, 2002a, p. 24).

A reestruturação produtiva, aqui entendida como acumulação flexível (Harvey, 2000), é fruto da tentativa do capital de conter/fazer regredir a crise estrutural do capital tomada como crise do modelo fordista-keynesiano na década de 1970. Este modelo, que se concretizou no pós-guerra, deve ser entendido como forma generalizada para organizar a produção material, calcada na aglutinação dos trabalhadores em grandes plantas industriais e como, segundo Harvey (2004), um modo de regulamentação social e político adequado a uma determinada etapa do capitalismo, monopolista, ou ainda uma determinada configuração da relação, indispensável ao capitalismo, entre capital, Estado e trabalho em uma dada fase (Antunes, 2000a).

Assim emerge, a partir dos anos 1970, um conjunto de estratégias burguesas que conjugam formas mais racionalizadas de organizar a atividade produtiva - acumulação flexível - e a oportunidade de pôr em prática um conjunto de preceitos que reformulam as formas de atuação do Estado - o neoliberalismo, que será caracterizado a seguir. No Brasil o processo de reestruturação produtiva inicia-se ainda nos anos 1980 e consolida-se nos anos 1990, exigindo, em poucos nichos, outros patamares de escolarização como formação para o trabalho simples 
issn: $1808-799 \mathrm{X}$

\section{ano 6 - número 7 - 2008}

e para o complexo. No que diz respeito às formas de organizar a produção, o paradigma flexível corresponde a uma forma de acumulação caracterizada pela desregulamentação dos mercados, inclusive do mercado de trabalho, pela redefinição espaço-temporal (global e imediatista) da ação do capital ${ }^{\text {xiii }}$, pelo predomínio do capital financeiro. Em relação à ação estatal, tem-se a privatização das empresas estatais, o corte de gastos sociais e pelo que Fontes (2005) denomina "ampliação seletiva" do Estado ${ }^{\text {xiv }}$.

Pode-se dizer que mudanças significativas no universo do trabalho exigiram um outro conjunto de qualificações técnicas e ético-políticas na formação humana da força de trabalho, no sentido de cumprir as necessidades do capitalismo em busca de sua reprodução ampliada. Mas não se trata, de modo algum, de se crer que vivemos em uma sociedade em que os interesses da burguesia e da classe trabalhadora convergem em uma sociedade da informação (Rodrigues, 2007; Lima, 2007). Ao se concentrar a atenção no mercado de trabalho atual, é possível observar, segundo Antunes (2000a), que a acumulação flexível corresponderia a uma intensificação da expropriação da força de trabalho, que se encarnaria através de processos de reengenharia, desconcentração produtiva, terceirização, eliminação de postos de trabalho, lean production, team work, aumento da produtividade e qualidade total, em uma extensão/adaptação do toyotismo ou de alguns de seus preceitos ${ }^{\mathrm{xv}}$. Para Fontes (2005), tratase de um processo em que, sob o predomínio da subsunção real do trabalho ao capital, retoma uma série de formas e mecanismos característicos da extração de mais-valia absoluta: trabalho a domicílio, trabalho por encomendas, por exemplo. A maior expropriação, segundo a autora, seria a do vínculo empregatício, vital no período anterior da acumulação capitalista ${ }^{\mathrm{xvi}}$.

Mas, segundo Neves e Fernandes (2002a), a reestruturação produtiva não se constituiria como único vetor de determinação para o crescente empresariamento da educação superior. O papel desempenhado pelo Brasil na economia mundial contemporânea corresponderia a outra importante determinação. Lima (2007, 2006), recuperando a obra de Florestan Fernandes, articula a reformulação da educação superior em curso desde os anos 1990 com o aprofundamento do padrão dependente de desenvolvimento.

Florestan estabeleceu, segundo Lima (2006), o conceito de capitalismo dependente a partir da combinação de dois vetores: as leis gerais que regem o desenvolvimento capitalista e as particularidades da formação social brasileira na divisão internacional do trabalho. Ao refletir sobre o desenvolvimento do capitalismo no Brasil, Florestan o faz a partir da forma como o país se integra à economia internacional. Esta integração, fruto do imperialismo, não é uma imposição externa, mas articula-se aos interesses de uma burguesia brasileira incapaz de formular um projeto autônomo de desenvolvimento nacional e que manter sua dominação 
issn: $1808-799 \mathrm{X}$

\section{ano 6 - número 7 - 2008}

econômica e ideológica, associa-se ao capital internacional, construindo o desenvolvimento subordinado econômica, política e culturalmente ${ }^{\text {xvii }}$.

Assim pode-se compreender como se delineou o padrão compósito da hegemonia burguesa no Brasil: como uma articulação complexa entre as velhas instituições oligárquicas e as relações patrimonialistas e as várias frações da burguesia local, em articulação subordinada à burguesia internacional, com o objetivo de manter e reforçar os privilégios das camadas dominantes e, simultaneamente, se ajustarem aos interesses socioeconômicos requeridos pelo capitalismo monopolista na produção da dependência dos países periféricos (Lima, 2006).

Os conceitos de padrão de desenvolvimento dependente e o padrão compósito de hegemonia burguesa constituem-se como elementos centrais para o entendimento do caráter dependente do ensino superior no Brasil. A instituição universitária no país, nascida como cópia dos modelos e conhecimentos gerados na Europa, guardava os dilemas oriundos da composição conservadora da burguesia em relação ao próprio desenvolvimento do capitalismo, que reivindicava a modernização do ensino superior em dois sentidos: na formação qualificada da força de trabalho e como elemento de formatação ideológica.

Ainda de acordo com Lima (2006), os anos 1960 marcam as disputas em torno da direção da educação superior no Brasil: enquanto professores e estudantes confrontavam-se com o padrão dependente de educação superior ${ }^{\text {xviii }}$, tendo como objetivos a efetiva democratização do conhecimento e da remodelação da estrutura interna das instituições de ensino superior, as frações variadas da burguesia buscavam submeter o terceiro grau a seus interesses. Como contra-revolução burguesa ${ }^{\text {xix }}$, o que se produziu foi uma orientação na direção de uma "reforma universitária consentida" (Fernandes apud Lima, 2007), em conjunção com os interesses da burguesia que moldaria as modificações de acordo com seus interesses ${ }^{\mathrm{xx}}$.

A reforma universitária conduzida pelo regime militar modificou a estrutura organizacional e institucional das universidades ${ }^{x \mathrm{i}}$ sem, no entanto, nenhuma ruptura com 0 padrão dependente de ensino superior, atendendo assim aos interesses da burguesia em estimular o crescimento econômico - o "milagre econômico" - e modernizar - sem transformar, ou modificando-a a partir de um padrão dependente - a educaçãoxxii.

A Constituição de 1988 manteve, como se verá mais adiante, a privatização do ensino, permitindo a obtenção de lucros às escolas laicas e a concessão de verba pública para o ensino privado ${ }^{x x i i i}$, característica que, aliás, a contra-reforma dos anos 1990 tornará ainda mais presente, aprofundando o padrão de dependência do ensino superior, o que, acompanha 0 
issn: $1808-799 X$

ano 6 - número 7 - 2008

aprofundamento do padrão dependente de desenvolvimento nos anos de acumulação flexível neoliberal.

Segundo Paulani (2007), nas décadas de 1970 e 1980 a concorrência intercapitalista modificou-se a partir de um processo de aquisições e fusões, iniciado com a crise dos anos 1970, que desencadeou a transnacionalização dos grandes grupos de capital, que reorientam a produção industrial e o universo de serviços a partir de formas de cooperação em nível mundial. A rigor, este processo, de acordo com Paulani (2007), implicará em novas estratégias dos grupos transnacionais, reconfigurando a inserção dos países periféricos na economia capitalista mundial.

"Entre os anos 1950 e 1970, o que as empresas multinacionais pretendiam, porque precisavam disso (buscavam novos mercados), era a internalização de duplicatas de suas plantas industriais na periferia do capitalismo. Já na década de 1990 o que marca a estratégia dos grupos transnacionais é a busca permanente de se livrar dos investimentos de longa duração, ganhando flexibilidade para explorar atividades lucrativas" (Paulani, 2007, p. 64).

Assim, as atividades desenvolvidas nos países periféricos são as mais simples (Frigotto, 2007, Neves e Fernandes, 2002a; Paulani, 2007) e montagem dos produtos e tecnologias, o que conduz a obsolescência do modelo de universidade baseado na indissociabilidade entre ensino, pesquisa e extensão. À educação superior, quando cabe formar para o trabalho complexo, se o faz dentro dos marcos de subordinação que marcam a inserção brasileira na divisão internacional do trabalho: a adaptação, cópia e montagem da tecnologia e formatação das mentalidades a uma cultura empresarial. Como afirma Gentili (2002), o papel das IES seria então formatar o indivíduo como força de trabalho para o capital e reproduzir as condições ideológicas da vida sob o capital, o que vem se estabelecendo no Brasil de Cardoso a Lula da Silva.

Entre os países centrais e periféricos estabelece-se, sob a tutela de organismos internacionais como o Banco Mundial e o FMI, uma desigualdade gritante no que tange à geração de renda, uma vez que o que atrai estes investidores é o baixo custo dessas operações, implicando subsídios por parte dos países ávidos por tais investimentos, bem como desregulamentação, precarização e flexibilização dos mercados de trabalho. No caso brasileiro, 
issn: $1808-799 \mathrm{X}$

ano 6 - número 7 - 2008

ao se impor a lógica neoliberal junto ao padrão compósito de hegemonia burguesa que se construiu historicamente, limitando a capacidade de pressão de setores "politizados" das classes trabalhadoras, o resultado é uma expropriação cada vez maior da força de trabalho, tanto sob a forma relativa quanto absoluta, remontando a condições muitas vezes desumanas de trabalho e uma redução da importância do setor industrial brasileiro, com a economia nacional caminhando, nos anos 1980 e 1990, para a desindustrialização ${ }^{\text {xxiv }}$, com a participação calorosa das elites nacionais na adoção da opção neoliberal como via milagrosa de modernização da economia nacional para a entrada no "admirável mundo novo" da globalização.

Assim, para Lima $(2007,2006)$ e Neves e Fernandes (2002a), dentre outros, os governos neoliberais - de FHC a Lula da Silva - não só mantiveram o padrão dependente de ensino superior, mas viabilizaram seu aprofundamento, como parte da estratégia burguesa para o enfrentamento da crise estrutural do capitalismo.

Segundo Neves e Fernandes (2002a), o terceiro vetor no qual se deve buscar as determinações para o empresariamento do ensino superior brasileiro hoje estaria:

\[ (\ldots) \text { nas estratégias do Estado de } \]
privatização dos serviços públicos, que se
destinam, em boa parte, a transferir recursos que
até então eram destinados, prioritariamente, à
reprodução da força de trabalho para aumentar a
produtividade e a competitividade empresariais,
em decorrência dos imperativos para a superação
da crise do capitalismo monopolista" (Neves e
Fernandes, 2002a, p. 28-29).

Como solução para a crise do capitalismo nos anos 1970, o padrão flexível de acumulação fez-se acompanhar de uma novas formas de atuação estatal. É então que a doutrina neoliberal, em elaboração desde $1947^{x \times v}$, encontra a oportunidade histórica de ser tomada com seriedade, na medida em que oferecia uma explicação para a crise e uma solução. O diagnóstico: o Estado Providência, com os gastos sociais, as concessões aos trabalhadores e a atuação interventora no mercado, impedia a competição e, portanto a prosperidade de todos, tolhendo a liberdade dos cidadãos (Chauí, 2006; Paulani, 2007). O remédio: um Estado forte para quebrar o poder dos sindicatos e das organizações operárias, criando um exército de reserva que enfraquecesse o poder da classe-que-vive-do-trabalho (Antunes, 2002) de negociar, capaz de garantir a estabilidade monetária a qualquer custo, capaz de controlar e limitar os gastos sociais e sua ação na economia, incentivando os 
issn: $1808-799 \mathrm{X}$

\section{ano 6 - número 7 - 2008}

investimentos privados, aliviando a carga tributária do grande capital, taxando maciçamente o trabalho, o comércio e o consumo. Em resumo: um Estado mínimo para o trabalho e máximo para o capital.

O neoliberalismo no Brasil avança desde o final dos 1980, ainda durante a primeira eleição para a presidência depois do governo militar, vencida com o discurso liberal-social de Fernando Collor de Mello, mas afirmou-se nos governos de Itamar Franco e, principalmente, nos dois mandatos de Fernando Henrique Cardoso, que comanda um grande processo de privatizações e a abertura da economia, preparada por uma série de medidas para que o país pudesse configurar-se como mercado financeiro emergente.

Segundo Neves e Fernandes (2002a), a partir de 1995 o Estado brasileiro implementa uma reforma em sua aparelhagem ${ }^{x \times v i}$, definindo as atividades de que deve se encarregar diretamente, aquelas que deve supervisionar e coordenar e aquelas que deve abrir à iniciativa privada. A educação torna-se a partir de então atividade não exclusiva do Estado, podendo ser oferecida por outras organizações públicas não-estatais e privadas. Assim, o Estado deveria focalizar sua atuação mais diretaxxvii, no âmbito educacional, no ensino fundamental e em programas de educação profissional. Nos outros setores, como no caso da educação superior, a oferta ficaria nas mãos das organizações sociais ${ }^{\text {xxviii }}$ (em geral, comunitárias, confessionais e filantrópicas) ou das empresas de prestação de serviços educacionais.

Dois traços parecem definir os rumos da privatização da educação superior: a transformação das instituições públicas em educação pública não-estatal e o estímulo à iniciativa privada que encontra aí importante espaço de acumulação de capital. No primeiro caso, afirma Lima (2004), de acordo com as políticas do BM e do FMI, as IES públicas, estabelecendo-se como organizações sociais, devem buscar outras fontes de financiamento, tornando-se universidades operacionais ${ }^{\text {xxix }}$ (Chauí, 1999). Seriam públicas pois prestam serviço público, mas deveriam se abrir aos recursos oriundos dos setores públicos e privados. Uma série de medidas tomadas pelo Estado vêm garantindo a precarização das universidades públicas, estabelecendo as vias para sua privatização.

O governo de Lula da Silva, através de um novo conjunto de reformas de cunho neoliberal, implementa na forma de leis, decretos e medidas provisórias a reformulação que aprofunda a precarização e privatização das universidades públicas bem como estimula o crescimento do setor privado.

Tais iniciativas vem sendo estimuladas também pela difusão das idéias de empregabilidade, de competências e habilidades que conduzem a busca pela população em 
issn: $1808-799 \mathrm{X}$

ano 6 - número 7 - 2008

geral desse nível de ensino ${ }^{x x x}$ e da qualificação pela educação como fonte de integração ao mercado de trabalho. Quanto mais educado, maiores seriam as chances do trabalhador $\mathrm{e}$ entrar e permanecer no mercado. Na medida em que o Estado age focalizadamente na educação fundamental, resta ao indivíduo buscar sua escolarização superior na iniciativa privada, uma vez que a rede pública, em sua atuação configuração não é capaz de atender a demanda. A novela "Duas Caras", exibida em horário nobre pela rede Globo de televisão não cessa de tentar reproduzir a idéia de que a educação superior deve ser conduzida pela iniciativa privada, mais eficiente e capaz de promover, finalmente, a democratização da educação superior no país.

Se desde o fim da ditadura já se configura em antecipação, para o ensino superior, a hegemonia da iniciativa privada, no final dos anos 1980 essa tendência se aprofunda, com a Constituição de 1988, e de modo mais incisivo, com a Lei de Diretrizes e Bases da Educação (LDB) permitindo a lucratividade representando importante vitória das frações burguesas e de suas entidades representativas, como a ABMES. Os anos 1990 trariam a política neoliberal de privatização dos serviços sociais, o que fez surgir uma nova burguesia de serviços (Rodrigues, 2007; Neves e Fernandes, 2002a ${ }^{\text {xxxi }}$, fração da burguesia bastante favorecida pela política neoliberal. Nesta fração, sobressaem-se os empresários da educação, especialmente no nível superior. Das 1.934 IES privadas, 1.520 pertencem aos empresários do ensino, número que pode estar subestimado, uma vez que parte das filantrópicas é, na verdade, empresarial.

Para Neves e Fernandes (2002a), esta burguesia de serviços educacionais é fruto das ações do Estado brasileiro na tentativa de restaurar a lucratividade de frações da burguesia e de instaurar uma nova hegemonia política, reconfigurando inclusive a atuação das entidades representativas da escola privadaxxii . No plano do ensino superior, destaca-se a ABMES, que em sua atuação mais recente busca configurar-se como elemento de pressão sobre o Estado, especialmente no que diz respeito ao financiamento - e à regulação/avaliação.

\section{A ABMES: entidade representante da burguesia de serviços educacionais no nível superior}

Contando, entre seus associados, com 294 mantenedoras e 350 instituições de ensino superior, a Associação Brasileira de Mantenedoras do Ensino Superior, ABMES (então ABM), foi criada em 1982 como resultado do crescimento acelerado do setor privado laico no âmbito 
issn: $1808-799 X$

ano 6 - número 7 - 2008

da educação superior. Com o objetivo de lançar-se como um dos "grupos de pressão que procuram articular pontos de vista particulares" (Thompson, 1998, p. 111) na elaboração de políticas públicas e governamentais para o terceiro grau, a ABM buscava assegurar os interesses dos empresários do ensino superior, sob a presidência e atuação centralizada do professor Cândido Mendes. A Constituição de 1988, no que diz respeito à educação superior, carrega as marcas de sua atuação em conjunto com outras entidades do representativas do setor privado, o que se pode aferir pela delimitação da educação como campo livre para a atuação da iniciativa privada, em busca da lucratividade, em igualdade de condições com o Estado $^{\text {xxiii }}$, dentre outras diretrizes ${ }^{\text {xxiv }}$ (Neves, 2002, p. 187). Conforme afirma a própria entidade:

"A ABMES tem-se destacado, desde sua criação, pela apresentação de subsídios à elaboração de políticas para o ensino superior. Para tanto, fez-se representar na Comissão Nacional de Reformulação da Educação Superior, no governo José Sarney, nos processos de discussão da Constituinte e da Lei de Diretrizes e Bases da Educação Nacional (LDB) e na elaboração dos planos de governo Fernando Collor e Fernando Henrique Cardoso" (ABMES, 2002, grifo nosso).

Além disso, ainda nos anos 1980, a Associação buscou, segundo Neves (2002), comunicar-se com a sociedade civil na tentativa de arregimentar apoio para a iniciativa privada no setor, bem como dirigir-se a seus pares na busca pelo fortalecimento da entidade. Duas iniciativas são importantes neste sentido: a criação da Revista Estudos e do projeto do Instituto Brasileiro de Qualificação do Ensino Superior (Ibques).

Segundo a própria entidade, a Revista Estudos, entre 1982 e 1991, reuniu uma série de artigos e estudos sobre

"o papel da escola particular para além do ensino; os rumos emergentes da educação superior; a educação particular e a Constituição; o financiamento, o peso e o desempenho do setor privado do ensino superior no Brasil; a coexistência com o setor público, a política de ensino superior e a emergência do pluralismo do ensino superior" (ABMES, 2006a) ${ }^{\mathrm{x \times v}}$. 
issn: $1808-799 \mathrm{X}$

\section{ano 6 - número 7 - 2008}

É curioso observar no trecho acima a presença de temas que, a partir dos anos 1990, serão alçados a uma importância maior para a entidade: a questão do financiamento, do pluralismo, a reverter-se na diversificação das IES e cursos, e do peso do setor privado, que serve como argumento para o financiamento público das instituições privada, por exemplo.

A outra iniciativa de interlocução com e pelos pares com a sociedade civil foi o projeto do Ibques (1991) que, segundo Neves (2002), teria como foco o problema da qualidade e da avaliação, dos quais ocupou-se ao longo da primeira metade da década de 1990. Para Neves (2002, p.189), a criação do Ibques responderia a uma demanda dos empresários educacionais: fornecer uma base técnico-científica que permitisse dar suporte às suas lutas políticas ${ }^{\text {xxvi }}$. De acordo com a ABMES (2006a), essa experiência ajudou a definir os rumos da Associação desde então: não avaliar, mas orientar e subsidiar os processos de avaliação interna das instituições associadas, valorizando os procedimentos centrados nos Projetos Pedagógicos das IES. Essa questão é importante, pois constitui-se como um ponto de tensão entre os representantes da nova burguesia de serviços educacionais e o governo nos anos 1990 e nos dias atuais. A ABM defende posição contrária a qualquer avaliação externa, entendendo a atuação fiscalizadora do Estado como aquele "que se impõe pelo autoritarismo" (ABMES, 2006a).

Os anos 1990 marcam um período de intensificação da atuação da Associação, na primeira metade da década, junto ao Conselho Federal de Educação (CFE), ao MEC e ao Congresso Nacional, mantendo a orientação de se dirigir ao governo no plano administrativo. No que tange ao CFE, autônomo em relação ao MEC na época, sua influência se manteve, permitindo a abertura de 38 universidades, das quais mais da metade pertencem à iniciativa privadaxxxvii. Já sua atuação junto ao MEC é irregular no período, segundo Neves (2002). De acordo com a autora, dois pontos se constituíram nos principais ponto de aproximação ou afastamento em relação ao Executivo federal no período: as anuidades escolares e o crédito educativo. Conforme documento da própria ABMES (2006a, grifos nossos), a Associação passou a estimular, "de maneira mais sistematizada", os debates sobre a LDB, de que se tratará a seguir, mas também sobre a "reforma constitucional, mensalidades escolares, crédito educativo, avaliação, definição de políticas nacionais, de educação superior e fortalecimento das relações com os órgãos governamentais e com os segmentos da rede privada". De alguma forma, parece que as preocupações com a "sustentabilidade" econômica das instituições já aparece em cena por conta das restrições econômicas características desta década, que se refletem no poder aquisitivo de sua clientela, sempre estruturalmente limitado (Carvalho, 2006). 
issn: $1808-799 X$

ano 6 - número 7 - 2008

Especialmente no governo de Itamar Franco, o conflito entre a entidade e o governo subsistiu, chegando até o Judiciárioxxviii para resolver a questão das mensalidades escolares. O programa de crédito educativo entrou em crise por causa da "indefinição das políticas oficiais" para o setor, o que se engendrava a falta de alocação de recursos para o programa e, a menos que outras fontes de financiamento fossem encontradas, a solução seria, de acordo com indicações do MEC, a redução do programa a partir de 1992. Obviamente, os empresários da educação superior e seus órgãos representativos reagiram, conseguindo estabelecer um acordo com o MEC de manutenção do programa, ao mesmo tempo em que novos alunos não seriam aceitos até a reformulação do programa. Em seguida, as representações privatistas passam a se dirigir ao Congresso Nacional na tentativa de fazer aprovar projeto de lei sobre 0 tema ainda em 1992, embate do qual saem vitoriosas, em destaque a ABM, sob nova direção, no sentido da aprovação de um projeto de lei que normatizasse uma política de crédito educativo e de garantia de sua participação na formulação de um novo programa que mantivesse a presença dos alunos carentes nas instituições ${ }^{\text {xxxix. }}$.

A Associação, ainda nesta fase, buscava atuar, com presença forte, na tramitação da Lei de Diretrizes e Bases da Educação (LDB), junto ao Congresso Nacional, bem como estabelecer uma convivência harmônica com outras entidades representantes do setor privado no sentido de fortalecer a defesa dos interesses deste setor ${ }^{x l}$. O projeto elaborado pelo senador Darcy Ribeiro foi apoiado pela ABM como ponto de partida mais profícuo para deliberação e defendido e apresentado pela Associação, tanto para o empresariado da educação quanto para a sociedade civil, como o mais "moderno" (Neves, 2002). Em linhas gerais, o projeto, aprovado pelo Congresso Nacional e sancionado pelo presidente Fernando Henrique Cardoso como a Lei n`9.394/96, garantiu a vitória dos privatistas (Neves, 2002; Lima, 2007).

Aliás, foi com a eleição de Fernando Henrique Cardoso para Presidente, em 1995, que a ampliação da atuação política da ABMES se deu. O governo FHC marca a o avanço do neoliberalismo no país, com uma maior abertura da economia e um acelerado plano de privatizações $^{\text {xi }}$, em um governo fortemente apoiado pela burguesia e por amplos setores das camadas médias urbanas.

De acordo com Lima (2007, p. 135), a crescente privatização da educação superior ocorrida durante o governo Cardoso segue duas estratégias principais: "a diversificação das IES e dos cursos e a diversificação de suas fontes de financiamento", o que certamente conduziu à aprovação do governo Cardoso pela $A B M$, que se reestrutura ao perceber a oportunidade de funcionamento mais orgânico do padrão neoliberal de atuação estatal, ao 
issn: $1808-799 \mathrm{X}$

\section{ano 6 - número 7 - 2008}

mesmo tempo em que reivindica o desenvolvimento do mercado interno e sustentado pela educação privada.

Essa reformulação passou por um aspecto organizacional (introdução de planejamento estratégico, redefinição de seu estatuto e a alteração, via concurso em âmbito nacional, de sua logomarca e nome para ABMES), sob o comando do reeleito Edson Franco, consolidando sua atuação direta na definição de políticas educacionais.

Importante ressaltar que desde meados dos anos 1990, a ABMES se orienta em torno da importância da empresa educacional no projeto neoliberal e ao redor dos aspectos favoráveis e desfavoráveis a sua atuação - o que comparece até hoje, como se poderá ver no documento aqui analisado (Neves, 2002, p. 203). Anuncia, em seu plano estratégico de gestão 1995-1998, os aspectos desfavoráveis a sua atuação:

"a falta de confiança da sociedade brasileira em relação às instituições de ensino superior e, especialmente, às instituições privadas laicas; o descompasso entre a lei e a realidade, com profusão de novas normas que dificultam a consolidação de um claro entendimento das mesmas; a legislação reguladora da remuneração de prestação de serviços educacionais, estimulando a inadimplência; a presença de um sistema de ensino superior 'alienígena' em nosso país; a falência do amparo constitucional de financiamento da pesquisa nas instituições privadas, dificultando a constituição de grupos de excelência; 0 forte controle governamental, fundado em indicadores de qualidade que conflitam com a legislação vigente; a redução do poder aquisitivo da classe média, desemprego e ameaça de recessão, contribuindo para restringir a demanda pelo ensino superior; a desunião entre as instituições privadas de ensino superior; a ausência de uma clara política industrial e de serviços voltada para a expansão do emprego; e a baixa qualidade de egressos do ensino médio" (ABMES notícias apud Neves, 2002, p. 204)

Os pontos favoráveis seriam:

"o crescimento quantitativo do ensino médio; o surgimento de novos nichos, tais como: cursos seqüenciais, ensino a distância, educação continuada, demandas do Mercosul, prestação de serviços, mediante programas de extensão; 
issn: $1808-799 X$

ano 6 - número 7 - 2008

dificuldades de alinhamento das universidades e instituições isoladas de ensino mantidas pelo Poder Público Federal, com a política que vem se estabelecendo visando obter fontes alternativas de recursos, além daquelas específicas do Tesouro Nacional; possibilidade de as instituições educacionais privadas do ensino superior virem a ser administradas como empresas; amplas necessidades de reciclagem de recursos humanos vinculados às empresas e aos governos; novas fórmulas adotadas pelo governo em relação à remuneração pela prestação de serviços por parte das entidades particulares de saúde" (ABMES notícias apud Neves, 2002, p. 204-205).

É apoiando-se nas em tais pontos favoráveis, que a ABMES encontrará as bases para reivindicar, junto ao Poder Público, medidas e iniciativas que permitam à iniciativa privada enfrentar os pontos desfavoráveis. É assim que a ABMES se organiza para a gestão 19982001, buscando, cada vez mais, a aproximação em relação ao MEC, CNE e o Congresso Nacional, bem como buscando fortalecer-se para enfrentar as regulações e avaliações que, no limite, entravam a livre-iniciativa em sua busca de lucratividade.

Além disso, pode-se afirmar, com base no documento abaixo analisado, que as questões orientadoras das ações e propostas da ABMES para os anos 2007-2011 continuam, em essência, ligadas aos pontos acima assinalados.

Uma análise do documento "Políticas Públicas para a Educação Superior: propostas do Setor Privado"

O documento "Políticas Publicas para a Educação Superior: propostas do setor privado" é apresentado como resultado do seminário "Educação como desafio para o desenvolvimento: proposições do setor privado", realizado nos dias 7 e 8 de novembro de 2006 em Brasília, visando o mandato do novo presidente da entidade entre 2007 e 2010. Tem como objetivo apresentar ao governo "(...) os subsídios e as aspirações da iniciativa privada (...)" (ABMES, 2006).

Após um Resumo Executivo, o documento de quarenta páginas se divide em duas partes. Na primeira são apresentados os "pressupostos relativos à educação e ao 
issn: $1808-799 X$

\section{ano 6 - número 7 - 2008}

desenvolvimento nacional, à responsabilidade social e à regulação do ensino superior" (ABMES, 2006). Os textos que compõem esta primeira parte foram extraídos das falas de representantes de IES que se apresentaram no Seminário. A segunda parte contém as proposições para o Governo Federal, divididas em três partes.

A primeira parte das propostas, compostas por dez itens, reúne-se sob o título de "Educação, produção de conhecimento e desenvolvimento nacional" e busca articular o ponto de partida (pressupostos) para as propostas da Associação. A primeira proposta trata logo de resgatar as garantias da Constituição de 1988 no que diz respeito ao lugar - lucrativo concedido à iniciativa privada no sistema de ensino superior. Mais que isso, afirma "(...) o dever e direito do setor privado de participar ativamente da formulação e execução das políticas públicas (...)" (ABMES, 2006, grifo nosso).

Em seguida, pede que o governo fortaleça iniciativas de expansão da oferta de cursos superiores que atendam aos mercados locais/regionais, especialmente nas áreas de desenvolvimento técnico, que suporte a empregabilidade e o empreendedorismo. Revela-se então não só a orientação para o mercado, mas também a presença do suporte ideológico da empregabilidade e do empreendedorismo como orientação para a formação: formar para atender ao mercado de trabalho e formatar ideologicamente o indivíduo à cultura de mercado são imperativos do sistema empresarial de ensino.

No terceiro item, a ABMES sugere que o governo estimule a diversificação das IES para que estas possam expandir-se em direção a localidades fora dos grandes centros ou metropolitanas, organizando novos mercados possíveis para a expansão do setor. No quarto sugerem que o governo estimule, junto às empresas, ao próprio governo e ao sistema educacional a demanda por conhecimento tecnológico e científico "(...) para que as IES possam cumprir seu papel de produtoras de conhecimento" (ABMES, 2006). Logo em seguida, sugerem que se fortaleçam os laços de confiança e parceria entre o Poder Público e as IES privadas, o que fortaleceria a credibilidade destas o que seria benéfico à sociedade.

Em seguida pedem que o sistema federal se integre ao mundo. Isso significaria a abertura da educação nacional aos investimentos e ingerências do capital estrangeiro, sob o álibi da cooperação internacional. No item 8 aponta para a possibilidade de cooperação interinstitucional na oferta de cursos e compartilhamento de instalações. Seria possível pensar em dois tipos de vantagem econômicas e de marketing. No primeiro caso, repartem-se os custos e riscos da iniciativa, e no segundo o peso de duas instituições ou marcas na oferta pode ser determinante para o sucesso do empreendimento. 
issn: $1808-799 X$

\section{ano 6 - número 7 - 2008}

O item $n^{\circ} 9$ requisita que o governo amplie o número e 0 atendimento aos alunos do PROUNI, uma das formas de financiamento público das IES privadas ${ }^{x l i i}$. Esse item certamente diz respeito ao fato de o PROUNI permite o acesso, mas os bolsistas nem sempre permanecem nas instituições devido, às vezes, a falta de condições. Segundo Carvalho (2006), cerca de $15 \%$ dos alunos matriculados no país via PROUNI abandonaram os cursos. Para remediar tal situação, o MEC, desde 2006 , concede bolsas de $R \$ 300,00$ para os bolsistas de cursos em tempo integral, o que atingiria apenas cerca de $2 \%$ dos alunos beneficiados pelo Programa. Daí a importância da ampliação do Programa.

O último item que anuncia os pressupostos faz referência à questão da regulação das instituições e dos procedimentos pedagógicos pelo MEC, considerada pela ABMES como autoritária e excessiva. O texto termina dando destaque ao 'problema' das limitações das atuais dimensões das turmas em sala de aula. Ora, turmas mais cheias são mais interessantes para as instituições pois assim estas podem disponibilizar apenas um professor, em geral, horista.

Em traços gerais, vê-se claramente a articulação das demandas da ABMES em duas direções: o financiamento público direto ou indireto da iniciativa privada e no enfraquecimento das regulações acadêmicas e administrativas realizadas pelo Poder Público, especialmente quando estas se interpõem entre as IES e o lucro.

$\mathrm{Na}$ segunda parte, as propostas tratam da regulação do ensino superior, anunciando de saída, que se trata de garantir a livre iniciativa ao setor, cabendo ao Estado apenas autorizar e avaliar a qualidade das instituições e cursos. As propostas relativas à regulação dividem-se entre aquelas relativas ao campo acadêmico, no que tange à graduação e à Pósgraduação/pesquisa, avaliação e relacionamento entre o ensino superior e a educação básica; ao campo administrativo, em relação à regulação, financiamento, supervisão, autonomia e tramitação de processos das IES.

No que se refere ao campo acadêmico, na instância da graduação, duas direções se destacam: a primeira, nos itens 1, 2 e 3 reforça a idéia de que seria necessário modificar os critérios de regulação das IES em relação ao modelo universitário, seja pela diversidade curricular que respeite as necessidades do cidadão e profissional do mundo atual, seja pelo cumprimento da indissociabilidade entre ensino, pesquisa e extensão de acordo com especificidades locais ou regionais e respeitando a autonomia das instituições, ou seja, sujeita a exceções, ou ainda pelo estímulo à oferta de cursos experimentais, não definidos no documento. Esse item reflete a crítica ao modelo de universidade de pesquisa, considerado, pelas forças mercantis, obsoleto e inadequado à realidade brasileira (Rodrigues, 2007). 
issn: $1808-799 X$

ano 6 - número 7 - 2008

A segunda direção refere-se ao trabalho dos docentes, expressas nos itens 4 e 5 . 0 primeiro trata da modificação do tempo de regime integral docente de 40 horas semanais para 36 horas, pois o regime de 40 horas é conflitivo com a Consolidação das Leis Trabalhistas (CLT). Logo em seguida, aponta com mais clareza: é preciso modificar - "flexibilizar"- as exigências de titulação e de tempo integral para os docentes das IES privadas, bem como adotar novos métodos para capacitar professores, pois isto estimularia a ampliação e atualização destes profissionais. É importante ressaltar que, de acordo com a Sinopse Estatística da Educação Superior - 2005, dos 201.841 professores que atuam na iniciativa privada, apenas 32.802 possuem regime de trabalho integral, ou seja, apenas 16,25\%, havendo ainda a possibilidade de que os planos de carreira que aparecem nestas instituições digam mais respeito à regimes de remuneração do que de trabalho (Léda, 2006). Assim, os dados apresentados na Sinopse poderiam estar superestimados.

Já no que diz respeito à Pós-Graduação e Pesquisa, comparece de saída a idéia de que - Estado deve fomentar a pesquisa científica e tecnológica nas IES privadas, estimulando parcerias com as agências de fomento (financiamento público direto) e as empresas. E mais: o Estado também deve oferecer incentivos fiscais para as IES que invistam em pesquisa, que ofereçam maior investimento em pesquisa e qualidade de ensino, bem como aos programas de intercâmbio e cooperação internacional. Propõe-se também que o governo incentive "formas alternativas de ensino", como a educação à distância - grande campo aberto para a exploração empresarial nacional e estrangeira-, educação pelo trabalho, educação aberta e não-formal.

$O$ item seguinte refere-se à avaliação. Em traços gerais, o que a ABMES requisita é uma revisão das formas de avaliação do governo em relação ao ensino superior, permitindo maior participação dos representantes do setor privado nas comissões e órgãos de avaliação e demais do MEC, aumentando assim o controle dos procedimentos e critérios de avaliação. Em segundo lugar, requisitam que sua "tradição" em processos auto-avaliativos seja considerada. Estes processos incluem a avaliação feita pelos clientes (alunos) sobre seus colaboradores (docentes), em uma relação de consumo, o que muitas vezes torna-se retaliação/premiação do docente capaz de agradar ao consumidor. Segundo a ABMES, a avaliação deveria orientar-se para os produtos e resultados e não para os meios. Neste sentido seriam beneficiadas pois produzem alguns resultados - democratização das oportunidades de acesso ao ensino superior - em ritmo acelerado e em número significativo.

É explicitada no documento a idéia de que os processos de avaliação das IES devem respeitar as diferenças entre o setor público e o privado, ou seja, um mesmo tipo de instituição 
issn: $1808-799 X$

\section{ano 6 - número 7 - 2008}

- a universidade, por exemplo - pública deve ser avaliada por métodos/processos diferentes da universidade privada.

Ao postular um subitem em que faz sugestões para uma maior e melhor articulação entre o ensino superior e a educação básica, a ABMES organiza três demandas diferentes. Em primeiro lugar recomenda que o Estado financie a formação de professores de ciência para o ensino médio, constituindo mais uma forma de financiamento público à iniciativa privada. Em segundo, requisita que o governo fortaleça o Fundo de Manutenção e Desenvolvimento da Educação Básica (Fundeb) para melhorar este nível de ensino, o que, por sua vez, melhoraria o nível dos alunos ingressantes ao ensino superior. O aluno mal-formado no ensino médio aqui apresentado como de responsabilidade do Estado - representa um problema para estas instituições por duas razões: a primeira é que, muitas vezes, este aluno abandona o curso pois não pode "acompanhar" as disciplinas. A segunda é que este aluno produz um resultado ruim nas avaliações promovidas pelo MEC, como, por exemplo, o Exame Nacional de Cursos (ENADE). E, por último, a formação para o capital: é preciso fortalecer o ensino de idiomas, especialmente o inglês e o espanhol, para a atuação no mercado global.

No campo administrativo, as propostas da ABMES que versam sobre a regulação da educação superior requisitam do governo maior liberdade administrativa, menor interferência do MEC nas instituições, mais uma vez colocada como "controladora e intervencionista". Para tal sugere: a criação de uma Agência Nacional de Educação Superior, autarquia com autonomia administrativa e financeira, vinculada ao MEC, tendo como função destacada garantir a livre-iniciativa o espaço no sistema federal de ensino superior, estabelecida pela Constituição de 1988, que também garante a autonomia, no caso das IES privadas, não interferência do Estado, bem como exercer a regulação e avaliação das IES.

O Estado também deveria, segundo a ABMES, garantir o cumprimento da LDB, tida como norma "flexível" que garantia "liberdade de ação" e impedir as interferências exercidas pelas Corporações, como a $\mathrm{OAB}$, por exemplo, que interferiria na regulação e avaliação dos cursos, competência do MEC. Além disso, as IES deveriam ter sua representação aumentada junto ao MEC, em seus órgãos e comissões, especialmente naquelas relativas à avaliação. $A$ ABMES parece buscar formas mais orgânicas de atuação junto ao MEC e ao Poder Público. Outro ponto, importante, requisita o aumento dos prazos para o estabelecimento da regularidade fiscal das IES que aderiram ao PROUNI.

No item financiamento, a tônica do documento é bastante clara: em primeiro lugar, a ABMES não cessa de demandar financiamento público (direto e/ou indireto) para a livre- 
issn: $1808-799 \mathrm{X}$

ano 6 - número 7 - 2008

iniciativa dada sua extensão e importância social como porta de entrada ao mundo do ensino superior. A demanda se estabelece como reivindicação direta, como no item 1, em que se reivindica efetivo financiamento público, tal como disposto pela Constituição, mesmo a fundo perdido em nome do "bem público e de mérito", como pedidos por "instrumentos alternativos de bolsas de estudo", para que o aluno possa escolher a instituição, como sugestão para utilização de recursos do Fundo de Amparo ao Trabalhador (FAT) para financiamento de alunos, que restituiriam os valores, como apelo por novas fontes de financiamento, como a permissão para a utilização de $50 \%$ do Fundo de Garantia por Tempo de Serviço (FGTS) e como pedido de isenção fiscal no que se refere aos produtos "(material didático, livros, móveis, etc), diminuindo os custos e, assim, aumentando o acesso de alunos.

O item supervisão também mantém uma mesma linha geral: é preciso tornar os procedimentos de avaliação menos intrusivos, mais rápidos e eficazes e os órgãos e comissões do MEC mais "abertos" e colaborativos em relação às IES privadas. O primeiro item já coloca que a supervisão deve: "Respeitar os princípios da descentralização e da hierarquia das leis no exercício da supervisão governamental das instituições privadas de ensino superior nos termos das competências estabelecidas pela Lei de Diretrizes e Bases da Educação Nacional" (ABMES, 2006, grifo nosso). Como a Constituição é a lei maior, e nela está garantida a liberdade e a lucratividade ao setor privado na educação, deve sobrepor-se a outras diretrizes, ainda que as IES devam ser minimamente competentes.

No que se refere à descentralização, um conjunto de medidas é sugerido: em primeiro lugar a criação de um Conselho Interministerial para o Desenvolvimento da Educação Nacional, para articular as políticas educacionais entre os vários ministérios que, direta ou indiretamente, promovam ou participem de projetos educacionais. Deveriam também participar desse Conselho as confederações nacionais ligadas aos setores de comércio, serviços, tecnologia, indústria e agronegócios e as associações que representam o ensino superior nacional tanto no segmento público quanto no privado. Aqui a educação superior, mais uma vez, encontra-se atrelada aos imperativos do capital, na medida em que são os representantes/articuladores de seus interesses que devem, junto ao Poder Público, definir as políticas educacionais.

Em seguida, solicitam a criação de uma Subsecretaria de Educação Superior Privada e de outra relativa ao ensino superior público, que se responsabilizariam pelos "atos autorizativos terminais de cursos e programas" (ABMES, 2006). Sugerem também a participação na indicação de representantes "para compor as Câmaras do Conselho Nacional de Educação", procurando assim ampliar sua atuação direta junto ao MEC, o que também transparece da indicação a necessidade de reuniões periódicas entre o MEC e as entidades representativas 
issn: $1808-799 X$

ano 6 - número 7 - 2008

das mantenedoras, "com pauta previamente definida, e com respostas e encaminhamentos de soluções dos problemas apresentados pelas representações" (ABMES, 2006, grifo nosso)

No item autonomia, mais uma vez, o tom é: retirar qualquer limitação relativa a gestão das IES privadas, tanto por parte do Poder Público quanto por parte das Corporações ou entidades reguladoras das atividades profissionais que "entravam" a livre-iniciativa, sempre recorrendo à Constituição e à LDB.

Para a ABMES, a autonomia deveria ser estendida para além das instituições de tipo universitário, para aumentar a liberdade financeira e administrativa das IES, revogando-se regulações excessivas. Além disso, as IES privadas requerem a possibilidade de registrar os próprios diplomas, para agilizar o recebimento do mesmo pelo aluno. Neste item, a ABMES já foi atendida pelo Governo Federal já facultou a qualquer universidade ou centro universitário a possibilidade de registrar diplomas, estabelecendo uma concorrência em que o melhor leva.

A última parte do documento, Tramitações de processos das IES, contém uma série de medidas relativas aos processos de autorização, reconhecimento, credenciamento e recredenciamento de cursos e/ou instituições. A ABMES aponta para a necessidade de menos entraves para o acompanhamento dos processos, de maior abertura do MEC e do CNE, bem como de maior agilidade do Poder Público nos processos.

O documento termina anunciando a esperança de que tais proposta encontrem acolhida favorável no novo governo, oferecendo-se para subsidiar o detalhamento das propostas bem como atuar junto ao Poder Público para o aperfeiçoamento de suas normas e processos, para possibilitar a expansão e qualificação do sistema de ensino superior no país, no qual a iniciativa privada seria indispensável. Parece que como produto do projeto de sociabilidade burguesa neoliberal, é mesmo.

\section{Considerações Finais}

Com base na análise do documento acima estabelecida à luz do contexto mais amplo em que se delineia um processo mundial de empresariamento da educação como forma de enfrentamento da crise estrutural do capitalismo, pode-se realizar algumas observações relativas aos embates no campo da educação superior nos próximos anos.

Em primeiro lugar, desenha-se, para as universidades públicas, um conjunto de ações que concretizam a contra-reforma, expressas no REUNI (Programa de Apoio ao Plano de 
issn: $1808-799 \mathrm{X}$

\section{ano 6 - número 7 - 2008}

Reestruturação e Expansão das Universidades Federais), formalizado pelo Decreto n 6.096/2007, que conduz ao desmantelamento da universidade de pesquisa e o regime de trabalho docente a uma aproximação às condições de trabalho nas IES privadas ${ }^{\text {xliii }}$.

A análise do documento elaborado pela ABMES revela que as IES privadas e suas entidades representativas preparam-se para enfrentar condições econômicas adversas oriundas do desemprego, da crise econômica que atinge as camadas populacionais urbanas que correspondem a seu público que, por sua vez, busca a escolaridade como condição da empregabilidade. Daí duas direções que sobressaem das propostas apresentadas pela ABMES ao MEC: a necessidade de crescente financiamento estatal - direto ou indireto - das IES privadas e a necessidade de maior liberdade administrativa, financeira e pedagógica - ou seja, a abertura perante qualquer prática pedagógica ou administrativa que sirva para manter as margens de lucratividade empresarial - para estas instituições, seguida pelo trabalho próximo ao Poder Público, em múltiplos níveis, na tentativa de dirigir as políticas educacionais nacionais a seu favor.

O segmento privado do ensino superior busca, junto ao Estado e a sociedade, seu fortalecimento econômico e sócio-político. No primeiro caso, os programas de bolsas de estudos e financiamento das mensalidades, como o PROUNI e o FIES são vistos como fundamentais, mas insuficientes. Daí a importância de sua ampliação bem como da emergência de outras formas de financiamento, inclusive de sua financeirização e do investimento internacional. No segundo caso, o setor privado busca encontrar formas de atuação cada vez mais diretas na definição de políticas educacionais, reivindicando cada vez maior participação junto aos órgãos públicos, comissões e conselhos, mas também, ao seu interesse, reivindicando autonomia e a não-interferência destas mesmas instâncias. Concomitantemente, atua junto à sociedade civil na tentativa de angariar uma imagem positiva de seu sistema de educação superior, apresentando-o como mais democrático, mais eficaz, mais desenvolvido e capaz de acompanhar as transformações da sociedade global. A rigor, o setor privado no nível superior se conduz de modo a contemplar as linhas de força do capitalismo tardio: a educação é lugar de reprodução da cultura empresarial, de suas práticas e valores, é espaço de formação para o mercado de trabalho e, mais que isso, é um espaço de acumulação capitalista dos mais significativos do arranjo neoliberal. 
issn: $1808-799 \mathrm{X}$

ano 6 - número 7 - 2008

\section{Referências bibliográficas}

1- Livros e artigos

ABMES. 2006. Políticas para a Educação Superior: propostas do Setor Privado. ABMES, Brasília, DF. Acesso: jan. De 2008. http://www.abmes.org.br.

2006a. ABMES 20 anos - Apresentação. ABMES, Brasília, DF. Acesso: jan. de 2008. http://www.abmes.org.br/sobre abmes/20anos/sumario.htm.

ALVES, Giovanni. 2005. Reestruturação produtiva e crise do sindicalismo. São Paulo: Boitempo editorial.

ANTUNES, Ricardo. 2000a. Os sentidos do trabalho. Ensaio sobre a afirmação e a negação do trabalho. São Paulo: Boitempo editorial.

(org.) 2000b. Neoliberalismo, trabalho e sindicatos. Reestruturação produtiva na Inglaterra e no Brasil. São Paulo: Boitempo editorial.

Boitempo.

(org.). 2006. Riqueza e miséria do trabalho no Brasil. São Paulo:

ANDERSON, Perry. 1995. Balanço do neoliberalismo. In: Pós-neoliberalismo: as Políticas Sociais e o Estado Democrático (SADER, E., org.) pp. 9-23, Rio de Janeiro: ed. Paz e Terra.

AZEVEDO, Mário Luiz Neves de. 2008. A Educação superior como um bem público: desafios presentes - teoria do capital humano, individualismo e organismos multilaterais. VII Seminário REDESTRADO - Nuevas Regulaciones em America Latina. CD-ROM, Buenos Aires: REDESTRADO.

BIN, Daniel. 2005. Subordinação funcionalista ao capitalismo neoliberal e mercantilização do ensino superior. $28^{\circ}$ Reunião Anual da Associação Nacional de Pesquisa e Pós-graduação em Educação (ANPED), Caxambu, MG. Acesso: jan. de 2008. http://www2.ueri.br/ anped11/.

BOTTOMORE, Tom. (ed.). 2001. Dicionário do pensamento marxista. Rio de Janeiro: Jorge Zahar ed.

CARDOSO, Miriam Limoeiro Cardoso. 2005. Sobre a teorização do capitalismo dependente em Florestan Fernandes. In: Democracia e educação em Florestan Fernandes (Fávero, O., org.) pp. 7-40, Campinas: Autores Associados; Niterói: Editora da Universidade Federal Fluminense (EdUFF).

2007. Sobre as relações sociais capitalistas. In: Fundamentos da Educação Escolar do Brasil Contemporâneo (NEVES, L.; LIMA, J., orgs.). pp. 25-66, Rio de Janeiro: editora Fiocruz/EPSJV.

CARVALHO, Cristina Helena Almeida de. 2006. Política para o ensino superior no Brasil (19952006): ruptura e continuidade nas relações entre público e privado. $29^{\circ}$ Reunião anual da Associação Nacional de Pós-Graduação e Pesquisa em Educação - ANPED. Caxambu, 2006. Acesso: jan. de 2008. http://www.anped.org.br/reunioes/29ra/29portal.htm.

CHAUÍ, Marilena. 2001. Escritos sobre a universidade. São Paulo. Editora UNESP. 


\section{trabalhonecessário ${ }^{2}$}

issn: $1808-799 \mathrm{X}$

ano 6 - número 7 - 2008

Paulo: Cortez.

2006. Cultura e democracia: o discurso competente e outras falas. São

CHAVES, Vera Lúcia Jacob. 2008. Expansão do ensino superior público brasileiro via precarização do trabalho docente. 2008. VII Seminário REDESTRADO - Nuevas Regulaciones em America Latina. CD-ROM, Buenos Aires: REDESTRADO.

COUTINHO, Carlos Nelson. 2007. O Estado Brasileiro: gênese, crise, alternativas. In: Fundamentos da Educação Escolar do Brasil Contemporâneo (NEVES, L.; LIMA, J., orgs.) pp. 173-200, Rio de Janeiro: editora Fiocruz/EPSJV.

CUNHA, Luiz Antônio. 1989. Universidade crítica: o ensino superior na República Populista. Rio de Janeiro: Francisco Alves.

DOURADO, Luiz. Fernandes. 2002. Reforma do Estado e as políticas para a educação superior no Brasil nos anos 90. Revista Educação \& Sociedade. Vol.23, n 80 (set.2002), Campinas. Acesso: jan. de 2008. http://www.scielo.br/.

CATANI, Afrânio Mendes; OLIVEIRA, João Ferreira de. 2003. Impasses e perspectivas das políticas para educação superior no Brasil. $26^{\circ}$ Reunião da Associação Nacional de Pesquisa e Pós-graduação em Educação (ANPED), Caxambú, MG.

FRIGOTTO, Gaudêncio. 2007. Fundamentos Científicos e Técnicos da Relação Trabalho e Educação no Brasil de Hoje. In: Fundamentos da Educação Escolar do Brasil Contemporâneo (NEVES, Lúcia M. W.; LIMA, Júlio C. F., orgs.) pp. 241-288, Rio de Janeiro: editora Fiocruz/EPSJV.

2001. A nova e a velha faces da crise do capital e o labirinto dos referenciais teóricos. In: Teoria e educação no labirinto do capital (FRIGOTTO, G.; CIAVATTA, M., orgs.) pp. 23-50, Petrópolis: ed. Vozes.

capital. Petrópolis: ed. Vozes.

CIAVATTA, Maria (orgs.). 2001. Teoria e educação no labirinto do

FONTES, Virgínia Maria. 2005. Reflexões im-pertinentes: História e capitalismo contemporâneo. Rio de Janeiro: Bom Texto.

GENTILI, Pablo. 1998. A falsificação do consenso: simulacro e imposição na reforma educacional do neoliberalismo. Petrópolis: ed. Vozes.

Petrópolis: ed. Vozes.

(org). 2005. Pedagogia da exclusão: crítica ao neoliberalismo em educação.

; SILVA, Tomás Tadeu da (orgs.). 2002. Neoliberalismo, qualidade total e educação. Petrópolis: ed. Vozes.

HARVEY, David. 2004. A condição pós-moderna. Uma pesquisa sobre as origens da mudança cultural. São Paulo: Edições Loyola.

INEP. 2008. Sinopse Estatística da Educação Superior 2006. Acesso: set. de 2008. http://www.inep.gov.br/superior/censosuperior/sinopse/default.asp.

KONDER, Leandro. 2001. Limites e possibilidades de Marx e sua dialética para a leitura crítica da história nesse início de século. In: Teoria e educação no labirinto do capital (FRIGOTTO, Gaudêncio; CIAVATTA, Maria, orgs.) pp. 98-114, Petrópolis: ed. Vozes.

KOSIK, Karel. 2002. Dialética do concreto. Rio de Janeiro: Paz e Terra.

LÉDA, Denise Bessa. 2006. Trabalho docente no ensino superior sob o contexto das relações sociais capitalistas. In: $29^{\circ}$ Reunião anual da Associação Nacional de Pesquisa e Pós- 
issn: $1808-799 X$

ano 6 - número 7 - 2008

graduação em Educação (ANPED). Caxambu, MG. Acesso: janeiro de 2008. http://www2.ueri.br/ anped11/.

. 2006. 'Correndo atrás': as repercussões da economia capitalista flexível no cotidiano do trabalho docente. VI Seminário REDESTRADO - Regulação Educacional e Trabalho Docente. UERJ, Rio de Janeiro, RJ. Acesso: janeiro de 2008. http://www.fae.ufmg.br/estrado/cd viseminario/trabalho eixo tematico.htm.

LIMA, Kátia Regina de S. 2004. Reforma universitária do governo Lula: o relançamento do conceito de público não-estatal. In: Reforma universitária do governo Lula: reflexões para o debate (NEVES, L., org.) pp. 23-46, São Paulo: Xamã.

2005. Dilemas e desafios para a construção de um projeto nacional de desenvolvimento: contribuições de Florestan Fernandes. In: Democracia e educação em Florestan Fernandes (Fávero, O., org.) pp. 41-53, Campinas: Autores Associados; Niterói: Editora da Universidade Federal Fluminense (EdUFF).

2006. Capitalismo dependente e 'reforma universitária consentida': a contribuição de Florestan Fernandes para a superação dos dilemas educacionais brasileiros. In: Educação Superior: uma reforma em processo (NEVES, Lúcia M. W.; SIQUEIRA, Ângela C. de., orgs.) pp. 19-42, São Paulo: Xamã.

Paulo: Xamã.

2007. Contra-reforma na educação superior: de FHC a Lula. São

MANCEBO, Deise; MAUÉS, Olgaízes; CHAVES, Vera Lúcia Jacob. 2006. Crise e reforma do Estado e da Universidade brasileira: implicações para o trabalho docente. Educar. N. 28, Editora UFPR, pp. 37-53. Acesso em set. de 2007. http://ojs.c3sl.ufpr.br/ojs2/index.php/educar/article/view/7610/5424.

NEVES, Lúcia Maria Wanderley. 2002. Rumos históricos da organização privatista. In: 0 empresariamento da educação: novos contornos do ensino superior no Brasil dos anos 1990 (NEVES, Lúcia M. W.; org.) pp. 179-220, São Paulo: Xamã.

(org.). 2002. O empresariamento da educação: novos contornos do ensino superior no Brasil dos anos 1990. São Paulo: Xamã.

reflexões para o debate. São Paulo: Xamã.

(org.). 2004. Reforma universitária do governo Lula:

; FERNANDES, Romildo Raposo. 2002a. Política neoliberal e educação superior. In: O empresariamento da educação: novos contornos do ensino superior no Brasil dos anos 1990 (NEVES, Lúcia M. W., org.) pp. 21-40, São Paulo: Xamã.

LIMA, Júlio César França Lima (orgs.). Fundamentos da Educação Escolar do Brasil Contemporâneo. Rio de Janeiro: editora Fiocruz/EPSJV, 2006.

; Siqueira, Ângela Carvalho de (orgs.). Educação Superior: uma reforma em processo. São Paulo: Xamã, 2006.

OLIVEIRA, Francisco de. 1995. Neoliberalismo à brasileira. In: Pós-neoliberalismo: as políticas sociais e o Estado democrático (SADER, E., org.) pp. 24-28, Rio de Janeiro: ed. Paz e Terra.

PAULANI, Leda Maria. 2007. O Projeto Neoliberal para a Sociedade Brasileira: sua dinâmica e seus impasses. In: Fundamentos da Educação Escolar do Brasil Contemporâneo (NEVES, Lúcia M. W.; LIMA, Júlio C. F., orgs.) pp. 67-105, Rio de Janeiro: editora Fiocruz/EPSJV. 
issn: $1808-799 X$

ano 6 - número 7 - 2008

POCHMANN, Márcio. 2007. Economia Brasileira Hoje: seus principais problemas. In: Fundamentos da Educação Escolar do Brasil Contemporâneo. (NEVES, Lúcia M. W; LIMA, Júlio C. F., orgs.) pp. 109-131, Rio de Janeiro: editora Fiocruz/EPSJV.

RODRIGUES, José. 2007. Os empresários e a educação superior. Campinas: Autores Associados.

SIQUEIRA, Ângela Carvalho de. 2002. Organismos internacionais, gastos sociais e reforma universitária do governo Lula. In: O empresariamento da educação: novos contornos do ensino superior no Brasil dos anos 1990. (NEVES, L., org.) pp. 47-71, São Paulo: Xamã.

THOMPSON, John. B. 1998. A mídia e a modernidade. Uma teoria social da mídia. Petrópolis: ed. Vozes.

VALE, Andréa A. do. 2008. O REUNI e a precarização do trabalho docente: uma análise comparativa com as condições de trabalho docente na iniciativa privada. 2008. VII Seminário REDESTRADO - Nuevas Regulaciones em America Latina. CD-ROM, Buenos Aires: REDESTRADO.

\section{2 - Periódicos}

CARTA CAPITAL, 2007. O ensino vai à Bolsa. Carta Capital, Ano XVIII, número 466, outubro de 2007.

FOLHA DE SÃO PAULO, 2005. Universidades privadas descumprem lei. Folha de São Paulo, 15 de ago, Folha Cotidiano, p. C1.

i Doutoranda no Programa de Pós-Graduação em Políticas Públicas e Formação Humana (PPFH) e professora do curso de Comunicação Social da Universidade Estácio de Sá desde 2002.

ii As IES podem, quanto a seu regime jurídico, ser públicas ou privadas. Estas se dividem em particulares ou confessionais, comunitárias e/ou filantrópicas. Este nível de ensino pode ser organizado academicamente em três tipos, de acordo com o Decreto $n^{\circ} 3.860$, de 09/07/2001: a) universidades (em que se mantém a indissociabilidade entre ensino, pesquisa e extensão), centros universitários e c) faculdades integradas, faculdades, institutos ou escolas superiores. Essa fragmentação é importante para a expansão da rede privada, como se verá mais adiante.

iii Esse é o tema de pesquisa de doutorado por mim desenvolvida no âmbito do programa de Políticas Públicas e Formação Humana (PPFH), na Universidade do Estado do Rio de Janeiro (UERJ).

iv O conceito de mediação designa os processos sociais - as essências - pelos quais se estabelecem as determinações estruturais e conjunturais de dado fenômeno histórico-social, articulados em uma totalidade concreta, conceito marxiano trabalhado por Kosik (2002, p. 43) que considera a realidade "como um todo estruturado em curso de desenvolvimento e de auto-criação". Trata-se de um conjunto de fatos em articulação histórica e dinâmica que se estabelece como resultado da ação dos sujeitos sociais.

$\checkmark$ A nova burguesia de serviços é formada pelo empresariado do setor de serviços que, se não detém o poder econômico dos grandes grupos industriais, cresce exponencialmente no período neoliberal brasileiro, como "herdeira" privilegiada das privatizações do período. Ver RODRIGUES, 2007; 2007a; Boito Jr, 2007.

vi Diante da atual configuração do setor - em que a expansão dos grandes conglomerados de ensino, articulados ao capital financeiro nacional e internacional, se faz às custas da concorrência avassaladora ("desleal") ou das fusões e aquisições das instituições de menor porte - faz-se mister salientar que, embora busquem, todos, a ampliação dos lucros do setor, os empresários de menor porte 
issn: $1808-799 \mathrm{X}$

ano 6 - número 7 - 2008

apresentam interesses em fratura perante aqueles dos grandes conglomerados. Em reportagem da Revista Conteúdo, Antonio Carbonari Netto, no comando da Anhanguera Educacional, pioneira na abertura de capital, em março de 2007, a concentração no setor educacional deverá atingir a seguinte proporção: apenas cerca de 20 grupos. "'O mercado hoje é vendedor, pois há muita gente saindo do ramo', afirmou em entrevista publicada no Jornal Gazeta Mercantil (maio/2008)". Revista Conteúdo. Os gigantes vão às compras. Revista Conteúdo. Brasília, agosto de 2008, número 1.

vii Dados retirados de: INEP. "Sinopse Estatística da Educação Superior 2006". Disponível em: http://www.inep.gov.br/superior/censosuperior/sinopse/default.asp, visitado em 03/01/2008.

viii Faz-se mister ressaltar que, nas IES públicas, a precariedade nas condições objetivas e subjetivas de trabalho avançam a passos largos, contribuindo para a privatização progressiva - e agressiva - das instituições bem como a crescente mercantilização do conhecimento. Ver MANCEBO et al., 2006. Ou seja, a expansão da iniciativa privada constrói-se sobre a precarização crescente das IES públicas.

ix As instituições públicas distribuem-se entre 105 IES federais, 83 IES estaduais e 60 IES municipais.

$x \quad$ Ingressos pelo vestibular e outras formas de acesso.

xi Afastados e em exercício.

xii Este número pode estar superestimado conforme se verá mais adiante.

xiii A análise deste mecanismo de expansão territorial do capitalismo é um dos grandes pontos das análises de Harvey. Ver Harvey, 2004.

xiv Segundo Fontes (2005), ao contrário do alguns autores entendem, o Estado neoliberal não é um Estado fraco, frágil. Pelo contrário age com força no sentido de garantir ao capital sua acumulação ampliada, atuando como artífice do processo de subordinação ampliada do trabalho ao capital. Para tanto, acompanhando o desmanche dos direitos sociais anteriormente conquistados, incorpora em sua aparelhagem formas de expressão organizadas, que seriam forma políticas correspondentes ao atual estado da correlação de forças entre capital e trabalho, tendendo em maior ou menor grau para o atendimento aos interesses do patronato. Neves e Fernandes (2002), Harvey (2004) e Lima (2006; 2007) também apontam para a mesma idéia.

xv Esta extensão/adaptação é estudada nos trabalhos de Antunes (2000) e Alves (2005) e, segundo estes autores, adquire formas bastante particulares e diferenciadas de área produtiva a área produtiva, região a região e país a país.

xvi Segundo Fontes (2005), embora um número cada vez maior de indivíduos pertencentes a classe trabalhadora não mais estejam submetidos à relações contratuais diretas com o capital, contribuem para sua acumulação, devendo, portanto, “... exercer sua atividade no ritmo e na intensidade socialmente requeridos" (Fontes, 2005, p. 95). Antunes (2006) também afirma que crescem as relações de trabalho desregulamentadas, sem a "proteção" das leis trabalhistas pela falta e vinculação contratual.

xvii Florestan Fernandes elabora suas análises da realidade brasileira e latino-americana a partir de sua inserção no sistema capitalista, inserção esta, porém, subordinada e articulada pelos interesses da burguesia brasileira. A partir do conceito de desenvolvimento desigual e combinado tal como considerado por Trotsky, de acordo com o qual, sob a vigência do imperialismo, as economias dos países menos desenvolvidos se configurariam como uma combinação de "desenvolvimento e subdesenvolvimento". Ver BOTTOMORE, 2001, p. 98-99.

xviii Pode-se definir padrão dependente de educação como o padrão educacional engendrado pelo lugar subordinado do Brasil na divisão internacional do trabalho e pelo tipo de organização da luta de classes formação econômico-social brasileira. Ver Lima, 2007.

xix De acordo com Lima (2006), a burguesia possui, contraditoriamente, potencial revolucionário, na medida em que historicamente assumiu seu papel de classe que conduziu ao rompimento com a ordem 
issn: $1808-799 \mathrm{X}$

ano 6 - número 7 - 2008

feudal. Mas, uma vez tornada classe dominante, a burguesia desencadeia um conjunto de práticas para impedir qualquer revolução contra seu poder de classe.

xx Estes interesses foram delineados no relatório elaborado pelo Grupo de Trabalho, constituído pelo Decreto $^{\circ}{ }^{6} 62.937 / 1968$, sob a batuta do ministro Tarso Dutra, do qual fizeram parte membros do CFE e professores universitários. Ver Cunha, 1989 e Lima, 2006.

xxi Segundo Cunha (1989), estas reformas implicaram na adoção do modelo norte-americano de gestão acadêmica, efetivada principalmente junto ao Conselho de Reitores. Tratar-se-ia da racionalização dos recursos humanos e materiais bem como da organização estrutural da universidade em departamentos como unidade central e do regime de disciplinas por crédito.

xxii Segundo Cunha (1989), o enrijecimento da ditadura militar a partir do Al-5 permitiu uma imposição da direção da reforma universitária na direção já esboçada anteriormente, atendendo aos interesses privatistas.

xxiii Esta alocação encontra-se delineada na revisão feita pelo Conselho Federal de Educação (CFE), em 1965, do Plano Nacional de Educação (PNE) de 1962, que modificava a destinação do Fundo Nacional do Ensino Superior, destinando 5\% deste em subvenções para universidades e estabelecimentos particulares. Em 1973, 39\% dos recursos públicos orientavam-se para as escolas particulares no ensino superior. Ver Cunha, 1988.

xxiv Para maiores detalhes, ver Pochmann, 2007.

xxv O economista F. Hayek, ainda nos anos 1930, começa a combater as políticas de tipo keynesiano em seus trabalhos. Em 1947, tomou a iniciativa de convocar grandes nomes do pensamento conservador, dentre eles Milton Friedman, para uma reunião em Mont Pelérin, na Suíça, com o objetivo de combater o keynesianismo e preparar o caminho para um novo capitalismo, livre de regulações. Ver Chaú, 2006 e Paulani, 2007.

xxvi Trata-se de reforma empreendida conforme o Plano diretor da reforma do aparelho de Estado.

xxvii A maior parte da atuação do Estado, no campo educacional, volta-se para a criação de mecanismos de regulação e avaliação do que na provisão direta de ensino.

xxviii Segundo Neves e Fernandes (2002), no Plano diretor da reforma do aparelho de Estado são definidas como organizações sociais como "entidades de direito privado, sem fins lucrativos, que tenham autorização específica do Poder Legislativo para celebrar contrato de gestão com o Poder Executivo e assim ter direito à dotação orçamentária" (Brasil/MARE, 1995 apud Neves e Fernandes, 2002, p. 28).

xxix Segundo Chauí (2001, p. 190), a universidade operacional corresponderia ao neoliberalismo dos anos 1990 e seria uma forma de adequar a universidade ao mercado, tornando-se a universidade atravessada por demandas e formas empresariais: " voltadas sobre si mesma como estrutura de gestão e de arbitragem de contratos. Em outras palavras, a universidade está virada para dentro de si mesma, mas, como veremos, isso não significa um retorno a si, e sim, antes, uma perda de si mesma"

xxx A este respeito ver Frigotto $(2007,2001)$, Neves e Fernandes (2002) e Lima (2007). A teoria do capital humano é retomada em um movimento de continuidades e rupturas em relação a sua clássica formulação nos anos 1960 e 1970, mas com outra entonação diante das mutações na ordem produtiva. "Esse modelo teórico não foi descartado nem o debate está esgotado, pois as bases do discurso em torno da teoria do capital humano continuam operativas. Isto é, a transnacionalização do capital e a implementação/consolidação da acumulação flexível do capital são compatíveis com os pressupostos da teoria do capital humano, ou melhor, em termos mais objetivos, a acumulação flexível demanda um modelo ideológico justificador do individualismo na educação, desresponsabilizando-se o Estado do projeto social de formação/qualificação e, no limite, da educação como um bem público". Azevedo, 2008, p. 12.

xxxi Estes autores seguem as reflexões de Boito Jr, 2007.

xxxii Para maiores detalhes, ver Neves e Fernandes (2002), Coutinho (2007) e Rodrigues (2007). 
issn: $1808-799 X$

ano 6 - número 7 - 2008

xxxiii Este é sempre um argumento aventado pela entidade quando se trata de apresentar suas propostas que, obviamente, beneficiam o setor privado: a garantia constitucional da igualdade entre o setor privado e a oferta pelo Estado no que diz respeito à educação em geral e à educação superior, em particular. Isso ficará claro quando tratarmos das propostas para o quadriênio 2007-2010.

xxxiv Outras iniciativas referem-se, por exemplo, ao lobby junto ao Conselho Federal de Educação (CFE), então de orientação claramente privatista. Ver Neves, 2002. A opção pelo lobby é enunciada pela própria ABMES: "evitar o enfrentamento judicial com os órgãos governamentais, procurando concentrar esforços nas instâncias administrativas" (ABMES, 2006a). Disponível em http://www.abmes.org.br/Sobre_ABMES/20anos/acoes.htm, acessado em janeiro de 2008. Mas nada impede que, uma vez o lobby derrotado, a via judicial seja logo adotada.

${ }^{x x x v}$ Disponível em http://www.abmes.org.br/Sobre_ABMES/20anos/acoes.htm, acessado em janeiro de 2008. Segundo Neves (2002), neste período, metade dos números da revista buscavam construir uma imagem positiva da escola privada, enquanto a outra metade dirigia-se a busca de novos associados e de arregimentar os antigos para o apoio das iniciativas e propostas da direção.

xxxvi É importante ter em vista a idéia de que o empresariado do ensino é uma importante fração da burguesia de serviços, que se não tem a força do setor industrial, vem sendo favorecida pelas políticas neoliberais de precarização e privatização dos serviços públicos. Neste sentido, a ABMES é entendida aqui como uma importante representação do sujeito coletivo empresariado do ensino nas lutas políticas e sociais no âmbito da educação superior. Ver Rodrigues, 2007.

xxxvii Neves (2002) levanta as regalias da ABMES junto ao CFE e aponta para a possibilidade de que estas tenham contribuído para a extinção do CFE e servido de álibi para a implementação do Conselho Nacional de Educação (CNE) submetido ao MEC.

xxxviii Para maiores detalhes, ver Neves (2002).

${ }_{x x x i x}$ Em 2005, o Programa Universidade para Todos (PROUNI) responderá a esta demanda.

xl Nos anos de neoliberalismo no Brasil, tanto as políticas de Estado quanto as formas de organização da sociedade civil passaram por um significativo processo de reorganização. É no bojo destas transformações que também se reorganizam as entidades representativas dos interesses da escola privada confessional e laica. Dada a divisão por tipo de instituições confessionais, comunitárias e filantrópicas, a Igreja Católica vai buscar uma organização mais eficiente para a atuação política no campo educacional. Neste contexto, são criadas a Associação Nacional de Mantenedoras de Escolas Católicas (Anamec), em 1993, que atua em todos os níveis, graus e modalidades de ensino, e o Conselho Nacional de Instituições de Educação Católica (Coniec), em 1994, integrado pela Anamec, pela Associação Brasileira de Escolas Superiores Católicas (Abesc), pela Associação de Educação Católica do Brasil (AEC), pela Conferência do Religiosos do Brasil (CRB) e pelo Movimento de Educação de Base (MEB), sob direção do setor educacional da Conferência Nacional dos Bispos do Brasil (CNBB). Após a eleição de Fernando Henrique Cardoso, também foi criada a Associação Brasileira das Universidades Comunitárias (Abruc), orientada para a defesa das universidades comunitárias, filantrópicas e confessionais em geral. A nova burguesia de serviços também reorganiza sua representação política, e o faz em duas etapas: na primeira metade da década de 1990 e a segunda após a aprovação da LDB e das demais medidas jurídicas. Após desgastes causados pelas disputas acerca da educação na Assembléia Constituinte, a Federação Nacional de Estabelecimentos Privados de Ensino (Fenen) - entidade sindical criada em 1948 e atuante no segmento das escolas laicas -, para não perder espaço como grande representante do segmento a partir da criação da Federação Interestadual das Escolas Particulares (Fiep), criou a Confederação Nacional dos Estabelecimentos de Ensino (Confenem), ambas concentradas atualmente no nível básico de ensino. Importante para a educação superior foi a criação, em 1989, da Associação Nacional das Universidades Particulares (Anup), atuando na década seguinte especialmente junto ao Conselho Nacional de Educação (CNE), ao Congresso Nacional e ao Ministério da Educação na defesa das universidades privadas, funcionando também como entidade de difusão ideológica dos interesses privatistas. A Associação Nacional dos Centros Universitários (Anaceu), criada em 1999, organiza os interesses dos centros 
issn: $1808-799 \mathrm{X}$

ano 6 - número 7 - 2008

universitários, atuando perante o Ministério da Educação e junto à Anup na defesa da iniciativa privada. A outra entidade representativa dos interesses empresariais no campo educacional é a Associação Nacional das Faculdades e Institutos Superiores (Anafi). Criada em 2001, a Anafi representa os interesses das faculdades integradas, faculdades isoladas e institutos superiores, especialmente em relação aos centros universitários e universidades.

xli De acordo com Paulani (2007), durante os anos 1980 preparou-se o país para sua entrada subordinada - no mercado financeiro internacional.

xlii Segundo Carvalho (2006), o PROUNI, entre sua idealização e a implantação legal, sofreu alterações no sentido da flexibilização dos requisitos e sanções e a redução da contrapartida das instituições. Por exemplo, não há na Lei, como havia no projeto, nenhuma sanção sob a forma de multa para o desrespeito às regras do Programa.

xliii A este respeito, ver Vale (2007). Chaves (2007), em recente trabalho, também mostra que a expansão do ensino superior públicas tem se desenvolvido a partir da lógica neoliberal que precariza as condições de trabalho nas instituições bem como as insere na lógica mercantil. O REUNI, que se concretiza a partir de contratos de gestão que estabelece uma série de metas, aprofunda a contrareforma do ensino superior, ampliando o número de alunos por docente sem as necessárias contrapartidas financeiras, com o aumento na contratação de substitutos. 